\title{
Spiegošanas un valsts nodevības krimināltiesiskais regulējums nacionālās drošības kontekstā
}

\author{
Mg. iur. Laura Platace \\ Rìgas Stradina universitāte, \\ Juridiskā fakultāte, Latvija
}

\section{Kopsavilkums}

Apstākḷos, kad valda geopolitiskais saspīlējums starp Rietumvalstīm un Krieviju, un apsteidzošas informācijas iegūšanas sāncensībā aktuāli kḷūst spiegošanas un valsts nodevības noziegumi. Taču kopš neatkarības atjaunošanas Latvijā neviena persona nav notiesāta par spiegošanu. Spēkā esošais Krimināllikuma regulējums ir nepilnīgs un nepietiekams, lai aizsargātu nacionālās drošības intereses, jo Krimināllikums valsts nodevību par noziegumu neatzīst, līdz ar to spiegošanas tiesiskais regulējums ir novecojis un nav piemērots pašreizējai situācijai.

Atslēgvārdi: spiegošana, valsts nodevība, nacionālā drošỉba, ārvalstu izlūkdienests.

\section{levads}

2014. gada laikā strauji mainījās geopolitiskie procesi Eiropā. Tie tieši ietekmēja Latvijas valsts drošību. Karadarbỉba Ukrainas austrumos ir izraisijusi politisko konfrontāciju starp Krieviju un Rietumvalstīm un drošības situācijas pasliktināšanos Eiropā, tāpēc ir pastiprināta NATO militārā klātbūtne Baltijas valstīs un Latvijas militārās aizsardzības spējas. Domāju, ka militārās aizsardzības stiprināšana ir tikai viens aspekts, lai novērstu valsts drošības apdraudējumus, jo ir mainījušās arī kara metodes. Mūsdienās tiek izvērsts hibrīdkarš un informatīvais karšs, kas ietver ne tikai militāras un vardarbīgas izpausmes, bet arī nevardarbīgu vēršanos pret valsts neatkarību, suverenitāti vai teritoriālo vienotību.

G̣eopolitiskā saspīlējuma apstākḷos valstīm aizvien aktuālāk kḷ̂ust iegūt apsteidzošu, publiski nepieejamu un klasificētu informāciju, kā arī "savervēt" sev aǵentus 
pretinieka pusē, lai varētu iegūt šādu informāciju vai saṇemt cita veida palīdzību. Vācijas Federālā konstitūcijas aizsardzības biroja vadìtājs H. G. Māsens ir uzsvēris, ka Krievija ir pastiprinājusi spiegošanas aktivitātes Eiropā, sasniedzot aukstā kara spiegošanas apmērus [25]. Aizvien aktuālāki kḷūst arī spiegošanas un valsts nodevības noziegumi.

Satversmes aizsardzības birojs (SAB) 2014. gada darbības pārskatā par vienu no nozīmīgākajiem valsts drošības iekšējiem un ārējiem apdraudējumiem ir nosaucis spiegošanu [22, 1]. Taču Latvijā līdz šim neviena persona nav notiesāta par spiegošanu ārvalsts izlūkdienestu uzdevumā.

Manuprāt, Latvijā krimināltiesiskais regulējums par spiegošanu ir nepilnīgs, arī Krimināllikuma (KL) regulējums neatzīst valsts nodevību par noziedzīgu nodarïjumu. Piemēram, Igaunijas Sodu kodeksa (SK) valsts nodevības regulējums par prettiesiskām darbībām atzīst ne tikai valsts noslēpuma un ārvalsts klasificētas informācijas vākšanu un nodošanu ārvalstij, bet arī ar vardarbību nesaistītu darbību veikšanu ārvalsts interesēs, ja rīcība vērsta pret valsts neatkarību, suverenitāti vai teritoriālo vienotību [7].

Tādēḷ pašreizējais krimināltiesiskais regulējums Latvijā nel̦auj personas saukt pie atbildības par tādiem nodarījumiem, kas būtiski apdraud Latvijas iekšējās un ārējās drošības intereses. Turklāt minētais problēmjautājums līdz šim Latvijā nav padziḷināti pètìts.

\section{Spiegošanas un valsts nodevības jēdziens un izpratnes attīstība pasaulē}

Izlūkošanas un drošības politikas pētnieki S. A. Teilors (S. A. Taylor) un K. Buhanans (K. Buchanan) skaidro, ka juridisko un konstitucionālo noteikumu vēsturiskie pirmsākumi, lai atturētu pilsoṇus no nodevības, bija domāti un bija cieši saistīti ar lojalitātes zvērestu un solïjumu valdniekam. Ja šie solījumi un zvēresti tika pārkāpti, tad pastāvošã vara varēja tikt sagrauta un iznīcināta, tostarp pats valdnieks un pati "valsts" [23, 518].

S. A. Teilors un K. Buhanans arī norāda, ka gan antīkās pasaules, gan 20. gadsimta tiesību filozofi uzskatīja nodevību par kaut ko vēl ḷaunāku nekā militārās informācijas nodošanu ienaidniekam. Drīzāk viṇi bija pārliecināti, ka nodevība grauj uzticību un apdraud vienotu pilsonisko sabiedrību, jo individuālas sabiedrības, tāpat kā civilizācijas, prasa lojalitāti. Šì prasība nav nepamatota, jo kopš aizvēstures laikiem līdz pat mūsdienām sociālā kārtība ir balstīta uz uzticēšanos. Par uzticību tika dots zvērests, tādēl uzticība no pilsoṇiem arī tika sagaidīta. Lai gan šādi zvēresti bieži tika lauzti, pārkāpumi nepalika nesodīti. Šāda izpratne par nodevību pastāvēja antīkajā pasaulē, viduslaikos un pastāv joprojām arī mūsdienās [23, 519].

Attīstoties politiskām un juridiskām sistēmām, lojalitāte pret valsti vai suverenitāti tika iekḷauta rakstītos likumos, lai izšḳirtu šādus noziegumus vai prasības pret lojalitāti valstij, tādēl gandrīz katrā modernā valstī par noziegumu ir atzìta valsts nodevība 
[23, 519-520]. Savukārt, kā skaidro izlūkošanas un drošības politikas pētnieki P. Gils (P. Gill) un M. Fitians (M. Phythian), spiegošana vēsturiski ir saprasta kā militārās izlūkošanas metode, lai noskaidrotu ienaidnieka mērksus un zagtu citu noslēpumus. Senajā Ėğiptē bija labi attīstìts slepenais izlūkdienests, kas vāca informāciju un ziṇoja valdniekam par ienaidnieka pozīcijām. Arī senajā Kīnā spiegošana tika izmantota kara mākslā, lai veiktu izlūkošanu un maldinātu ienaidnieku. Viduslaikos attīstījās politiskā spiegošana: karaḷnamu galmos tika uzpirkti galminieki, lai viṇi spiegotu citu ieinteresētu personu labā un nodotu tām uzzināto informāciju. [6, 10-11]

P. Gils un M. Fitians norāda, ka līdz pat mūsdienām spiegošana tiek saprasta kā likumu pārkāpšana, lai ārvalsts, izmantojot pretējās puses vājības, ar viltu un maldināšanu iegūtu slepenu informāciju, taču, lai tiktu pie noslēpumiem, tos vajag nolaupìt. Savukārt nolaupī̌šna notiek vai nu ar ielaušanos un zādzību, vai arī pamudinot citas personas uz nodevību uzpirkšanas, šantažěšanas vai, ja nepieciešams, tiešas fiziskas vardarbỉbas cel̦ā $[6,12-14]$.

N̦emot vērā minēto, secināms, ka spiegošanas un valsts nodevības jēdzieni ir cieši saistīti, jo, spiegojot citas valsts labā, valstspiederīgais nodod savu lojalitāti un izdara noziegumu pret savu valsti, bet spiegošana ir metode informācijas iegūšanai par pretinieku.

S. A. Teilors un K. Buhanans [23, 520] skaidro, ka mūsdienās jēdziens "valsts nodevība" valstu krimināllikumos tiek skaidrots un saprasts dažādi, bet kopumā valsts nodevība tiek definēta kā noteikta veida darbības, kas tiek uzskatītas par valstij nodevīgām. Visbiežāk valsts nodevība tiek definēta kā palīdzības vai atbalsta sniegšana ārvalstij, kas apdraud valsts drošību, vai kā nodevīga darbỉba, kuras rezultātā tiek mēginināts izraisīt karastāvokli pret valsti, vai kā savtīgas darbības ar mērḳi atbalstīt ienaidnieku. Savukārt P. Gila un M. Fitiana skaidrojumā $[6,14]$ jēdziens "spiegošana" visbiežāk tiek definēts kā slepenas informācijas vākšana ārvalsts interesēs.

Salïdzinot Eiropas valstu krimināllikumos ietvertos "valsts nodevības" jēdzienus, redzams, ka Vācijas Kriminālkodeksā (KK) valsts nodevības jēdziens tiek izmantots divējādi atsevišş̧os pantos:

1) kā noziedzīgs nodarījums ar vardarbīgu vēršanos pret valsts neatkarību un teritoriālo vienotību (81. pants);

2) kā valsts noslēpuma paziņošana ārvalstij (94. pants).

Savukārt ar spiegošanu tiek saprasta valsts noslēpuma izspiegošana (96. pants) [26].

Lietuvas KK valsts nodevība tiek attiecināta tikai uz kara laiku, ko ilustrē 117. pants: "Lietuvas Republikas pilsonis, kas kara laikā vai pēc kara stāvokḷa pasludināšanas pārgājis ienaidnieka pusē vai palīdzējis ienaidniekam darboties pret Lietuvas valsti, .." [16].

Igaunijas SK izpratnē valsts nodevība ir Igaunijas pilsoṇa sniegta palīdzība ārvalstij ar vardarbību nesaistītu rīcību, kas vērsta pret Igaunijas neatkarību, suverenitāti vai teritoriālo vienotību, vai valsts noslēpuma, vai ārvalsts klasificētas informācijas vākšana ar nolūku to nodot vai tās nodošana ārvalstij (232. pants) [7]. 
Uzskatu, ka "valsts nodevības" jēdziens ir plašāks nekā spiegošana, jo aptver arī "spiegošanas" jēdziena būtību. Tas ir novērojams Igaunijas SK regulējumā, bet vistiešāk tiek atrunāts Krievijas KK. Krievijas KK izpratnē valsts nodevība ir Krievijas pilsoṇa veikta spiegošana, valsts noslēpuma nodošana ārvalstij vai finansiālas, materiāli tehniskas, konsultatīvas vai cita veida palīdzības, kas vērsta pret Krievijas drošỉbu, sniegšana ārvalstij (275. pants) [11].

Igaunijas un Krievijas krimināllikumos, līdzīgi Vācijai, ar valsts nodevību tiek saprasta palīdzības sniegšana ārvalstij un valsts aizsargātas informācijas vākšana un nodošana ārvalstij. Vienīgā atšḳirība no Vācijas - Igaunijā un Krievijā palīdzība ārvalstij tiek saprasta kā palīdzība ārvalstij nevardarbīgi vērsties pret valsti. Turklāt valstīs, piemēram, Igaunijā un Krievijā, kurās "valsts nodevības" jēdzienā ir ietverta arī spiegošana vai spiegošanu raksturojošas pazīmes, tiek izdalīti divi noziedzīgi nodarījumi ar diviem atškirīgiem subjektiem. Par valsts nodevību soda pilsoni, bet par spiegošanu - ārvalstnieku.

Savukārt "spiegošanas" jēdziens ir attiecināms tikai uz aktīvu un slēptu darbību veikšanu, lai ārvalstij darītu zināmu valsts aizsargātu informāciju. Piemēram, Krievijas KK ar spiegošanu tiek saprasta valsts noslēpuma nodošana, vākšana, nolaupīšana vai glabāšana ar nolūku nodot to ārvalstij, kā arī citu ziṇu nodošana vai vākšana ārvalsts izlūkdienesta uzdevumā ar nolūku izmantot tās pret Krievijas drošību, ja to veicis ārvalsts pilsonis vai bezvalstnieks (276. pants) [11].

Igaunijā spiegošanas noziegums tiek raksturots tāpat kā 232. pantā teiktais par valsts nodevỉbu. Igaunijas SK izpratnē spiegošana ir valsts noslēpuma vai klasificētas informācijas vākšana nolūkā nodot vai tās nodošana ārvalstij, par ko soda ārvalstnieku (234. pants) [7]. Savukārt Lietuvas KK izpratnē spiegošana ir valsts noslēpuma nolaupīšana, nopirkšana vai citāda veida vākšana nolūkā to nodot, kā arī nodošana ārvalstij vai citu ārvalsts izlūkdienestu interesējošas informācijas nodošana (119. pants) [16].

Salīdzinot vairāku valstu krimināltiesisko regulējumu par spiegošanas un valsts nodevības jēdzienu izpratni, redzama atškirīga iepriekš minēto jēdzienu izpratne, taču mūsdienās joprojām valstu krimināltiesību regulējumos tiek atzīti abi jēdzieni - gan "spiegošana", gan "valsts nodevïba".

\section{Spiegošanas un valsts nodevības izpratnes attīstība Latvijā}

Sīkāk apskatot jēdzienu "spiegošana" un "valsts nodevība" izpratnes attīstību Latvijā kopš 20. gadsimta sākuma, redzams, ka 1903. gada 22. marta Sodu likumos, kurus Krievijā apstiprināja Nikolajs II 1903. gada 22. martā, bet Latvijā oficiāli ieviesa ar 1918. gada 6. decembra Latvijas Tautas Padomes izdoto likumu, kas bija spēkā līdz 1933. gada 1. augustam [13], ceturtajā nodaḷā bija iekḷauti dažādi noziegumu veidi, ko uzskatiija par valsts nodevỉbu $[1,35-40]$. 
Sodu likumu 108. pants paredzēja: "Latvijas pilsonis, kas pabalstīijis ienaidnieku vai rīkojies viṇam labvēlīgi kara vai citos kādos naidīgos darbos pret Latviju, sodāms: ar spaidu darbiem uz noteiktu laiku" [1,35-36]. Taču šajā pantā bija ietverts vēl sīkāks regulējums, kas diferencēja un atrunāja izdarìtos noziegumus un soda apmēru par pabalstī̌sanu vai labvēlīgu rīcỉbu. Piemēram, ja tāda pabalstišana vai ienaidniekam labvēlīga rīcība pastāvējusi: “.. 6) spiegošanā, .. tad vainīgais sodāms: ar nāves sodu” [1,36].

Par valsts nodevību tika uzskatīti dažāda veida noziegumi, piemēram, nodarijumi pret karaspēku (108. un 109. pants), vardarbīga vēršanās pret Latviju (110. pants), prettiesiskas darbības bez pienācīgas aț̣aujas (112.-113. ${ }^{1}$ pants), dokumentu viltošana (117. pants) u. c., ko likumdevējs bija uzskatījis par sodāmiem [1,35-39]. Taču jāuzsver, ka detalizēts regulējums bija izstrādāts par informācijas nodošanu ārvalstij, kas satur spiegošanas pazimes.

Sodu likumu 111. pants paredzēja: "Kas palīdzējis ārvalsts valdībai vai aǵentam ievākt ziņas vai priekšmetus, kuri attiecas uz Latvijas ārējo drošību vai viṇas bruṇotajiem spēkiem, vai valsts kara apsardzībai nolemtiem ierīkojumiem, sodāms: ar ieslodzijjumu pārmācības namā" [1,37]. Arī par informācijas nodošanu ārvalstij bija izstrādāts detalizētāks regulējums, kas diferencēja un atrunāja izdarītos noziegumus un soda apmēru, piemēram, ja kāds pārdevis vai pieteicis priviligéěsanai ārvalstì turamu izgudrojumu (111. ${ }^{4}$ pants), nodevis slepenībā turamas ziṇas un priekšmetus (111. ${ }^{1}$ pants), sadarbojies ar ārvalsts valdību, lai ievāktu informāciju (111. ${ }^{2}$ pants); kā arī atseviškịi bija atrunāts par informācijas vākšanu un nodošanu kara laikā (118. ${ }^{2}$ pants) u. c. [1, 37-39].

Sodu likumos ceturtajā nodạ̣a par izdarīto noziegumu subjektu bija noteikts Latvijas pilsonis, taču 119. pantā bija atruna: "Ārzemnieks, kas pa savu uzturēšanās laiku Latvijā izdarījis 108. pantā paredzētu noziedzīgu nodarījumu, vai šādā noziegumā vainīgais kara gūsteknis, ja viṇi nav atbildīgi pèc kara likumiem, sodāmi uz minētā panta pamata kā Latvijas pilsoṇi” [1, 40]. Ārzemnieks tika sodīts pēc valsts nodevības regulējuma, bet būtībā - par spiegošanu.

Latvijā 1933. gadā stājās spēkā jauns Sodu likums, kam Latvijas jurists, politiḳis un Latvijas 1933. gada Sodu likuma izstrādāšanas komisijas priekšsēdētājs P. Mincs devis detalizētu ietvertā regulējuma skaidrojumu. P. Mincs par šã likuma sesto nodaḷu "Valsts nodeviba" skaidroja, ka Latvijas Sodu likuma 87. pants soda ar spaidu darbiem uz noteiktu laiku Latvijas pilsoni, Latvijā dzīvojošu ārzemnieku un kara gūstekni (102. pants), kas pabalstījuši ienaidnieku viņa karā vai citos naidīgos darbos pret Latviju. Sods pieaug līdz spaidu darbiem uz visu mūžu "sevišḳi svarīgos gadījumos", kuru noteikšanu Latvijas Sodu likums, sekodams jaunajam virzienam leǵislatīvā tehnikā, atstājis tiesai. Šis nodarījums tādā pašā mērā sodāms, ja tas vērsts pret ārvalsti, kura karo savienībā ar Latviju (100. pants) [17, 49].

P. Mincs norāda, ka pēc 88. panta ar spaidu darbiem uz noteiktu laiku sodāms Latvijas pilsonis, kas stājies sakaros ar ārvalsts valdību vai tās aǵentu nolūkā panākt karu vai citus naidīgus darbus pret Latviju, vai pirms kara pieteikšanas apsolïis ārvalsts valdībai, savā vai citu vārdā, palīdzēt viṇai kara darbos pret Latviju. Sods paaugstināts 
līdz spaidu darbiem uz visu mūžu "sevišḳi svarīgos gadījumos". Ja iepriekšējās divas nodarījumu kategorijas var uzskatīt kā ieroču vēršanu pret tēviju vai vismaz kā kara briesmu tiešu tuvināšanu, tad vairāki citi Soda likuma panti attiecas uz t. s. "kara noslēpumu izpaušanu" [17, 49].

P. Mincs norāda, ka pie tiem pieder:

1. Ārējās drošības labā slepenībā turamu ziṇu, zīmējumu, plānu, dokumentu vai priekšmetu izpaušana vai nodošana bez pienācīgas aț̣aujas, par ko 89. pants draud ar spaidu darbiem līdz astoṇiem gadiem, bet "seviški svarīgos gadijumos" ar spaidu darbiem uz noteiktu laiku. Par tā paša nodarījuma izdarīšanu aiz neuzmanības 90. pants paredz pārmācības namu vai cietumu $[17,50]$.

Ārvalsts valdības vai aǵenta pabalstî̌̌ana 89. pantā minēto ziṇu u. c. vākšanā vai vienošanās ar viņiem par to (spiegošanas pabalstišana) - 91. pants soda ar pārmācības namu. Mēginājums - sodāms [17, 50].

2. Ievērojot lielās briesmas, kas rastos, atklājot valsts aizsardzības līdzekḷus, 92. pants paredz sodu arī par nodarījumiem, kas satur sagatavošanos minētajiem noziegumiem, proti: par 89. pantā minēto ziṇu u. c. vākšanu vai izgatavošanu bez pienācīgas aț̣aujas, telegrāfa, telefona vai radioiekārtas ietaisišanu vai pasta baložu turēšanu šo ziṇu vai priekšmetu ievākšanai vai nosūtišsanai. Sods - cietums, savienots ar minēto ietaišu vai baložu konfiskāciju [17, 50].

Ja 1903. gada Sodu likumos un 1933. gada Sodu likumā ar valsts nodevību tika saprasti dažāda veida noziegumi, tostarp ar spiegošanas pazīmēm, tad 1961. gada Lat vijas Padomju Sociālistiskās Republikas (PSR) KK ir skaidra definīcija, kuras nelikumīgās darbības Padomju Sociālistisko Republiku Savienībā (PSRS) ir valsts nodevība un kuras - spiegošana.

Latvijas PSR KK 59. pantā ir sniegta dzimtenes nodevības jēdziena definīcija: "Par dzimtenes nodevību, tas ir, par PSRS pilsoṇa ar nodomu izdarìtu nodarijumu, kas kaitē PSRS valsts neatkarībai, teritoriālajai neaizskaramībai vai militārajai varenībai: pāriešanu ienaidnieka pusē, spiegošanu, valsts vai militārā noslēpuma izpaušanu ārvalstij, bēgšanu uz ārzemēm vai atteikšanos atgriezties no ārzemēm PSR Savienībā, palīdzības sniegšanu ārvalstij tās naidīgajā darbībā pret PSRS, kā arī par sazvērestību nolūkā sagrābt varu" [14, 28-29].

Latvijas PSR KK izpratnē dzimtenes nodevība bija vissmagākais noziegums pret valsti. Šāds noziegums apdraudēja PSRS ārējo drošību, jo bija vērsts pret valsts suverēno neatkarību, teritoriālo neaizskaramību un militāro varenību. PSRS Konstitūcijā un Latvijas PSR Konstitūcijā bija pasludināts, ka tēvijas aizsardzība ir viena no svarīgākajām valsts funkcijām un ir visas tautas lieta [15, 211].

Latvijas PSR KK 60. pantā bija noteikta atbildība par spiegošanu: "Par ziṇu, kas ir valsts vai militārs noslēpums, nodošanu, kā arī nozagšanu vai vākšanu nolūkā tās nodot ārvalstij, ārvalsts organizācijai vai to aǵentūrai, kā arī citu ziņu nodošanu vai vākšanu ārvalsts izlūkošanas iestāžu uzdevumā, lai tās izlietotu pret PSRS interesēm, ja spiegošanu izdarījis ārvalsts vai bezpavalstnieks" [14, 29]. Par spiegošanu kriminālatbildỉba bija 
paredzēta ārvalsts vai bezpavalstniekam, bet dzimtenes nodevības subjekts varēja būt tikai PSRS pilsonis, kas sasniedzis 16 gadu vecumu. Ārvalstnieki un bezpavalstnieki varēja tikt saukti pie kriminālatbildības par līdzdalību dzimtenes nodevībā, ko izdarījis PSRS pilsonis [15, 212-218].

Ar 1991. gada Latvijas KK regulējumu "valsts nodevības" jēdziens tika iznememts no Latvijas krimināltiesiskā regulējuma. Savukārt "spiegošanas" jēdziena definīcija bija loti tuva iepriekšejjai Latvijas PSR KK. Latvijas KK ar spiegošanu tika saprasta valsts vai militāru noslēpumu saturošu ziņu nodošana, kā arī nozagšana vai vākšana nolūkā tās nodot ārvalstij, ārvalsts organizācijai vai tās ağentūrai, kā arī citu ziṇu nodošana, kā arī nozagšana vai vākšana ārvalsts izlūkošanas iestāžu uzdevumā, lai šìs ziṇas izmantotu pret Latvijas Republikas interesēm (60. pants) [20].

Arī spēkā esošā KL regulējumā par noziegumu ir atzīta tikai spiegošana. Ar spiegošanu tiek saprasta neizpaužamu ziņu un valsts noslēpuma nodošana, kā arī nolaupīšana vai vākšana ārvalstu izlūkdienestu uzdevumā, lai šis ziṇas izmantotu pretēji Latvijas Republikas interesēm (85. pants) [12]. Spēkā esošā KL izpratnē spiegošanas definīcija pēc būtības ir pārṇemta no Latvijas PSR KK. Būtiskākā atškịirība ir saskatāma attiecībā uz personu, kam piemēro atbildību par spiegošanu. Autore uzsver, ka šāda atškirīiba ir tādēl, ka KL noziedzīgu nodarījumu grupa, kuru varētu apzīmēt kā valsts nodevību un kuras subjekts būtu tikai pašas valsts pilsonis, nav izveidota, kā to ir atzinusi V. Liholaja [17, 23-52].

Manuprāt, atbildība un "valsts nodevības" jēdziens KL nav ietverts tā vēsturiskās nozīmes dẹl, jo asociējās ar Latvijas atrašanos PSRS sastāvā un totalitāras varas centieniem apspiest savu pilsoṇu politisko un sabiedrisko domu. Turklāt U. Krastiņš skaidro, ka KL projekta izstrādes sākumā vairākas normas tika izslēgtas kā valsts politiskajai vai ekonomiskajai situācijai neatbilstīgas vai novecojušas, kā arī atsevišķos gadījumos tika n̦emtas vērā Latvijas 1933. gada Sodu likuma nostādnes. No valsts noziegumu skaita tika izslēgta norma, kurā bija paredzēta atbildība par dzimtenes nodevību (Latvijas PSR KK 59. pants), atzīstot, ka jēdziens "dzimtene" nav juridisks jēdziens un šā vārda jēga likumpiemērošanas praksē var tikt dažādi interpretēta [10, 14]. Jāpiekrīt U. Krastiņa paustajai atziṇai, ka "dzimtenes nodevība" nav tiesību zinātnes jēdziens, mūsdienās demokrātiskas valstis, piemēram, Vācija, Igaunija, Lietuva, krimināltiesiskajā regulējumā izmanto terminu "valsts nodevība". Šo valstu prakse rāda, ka šādu jēdzienu iekḷaušana krimināltiesiskajā regulējumā netiek uzskatīta par novecojušu.

Vēsturiski Latvijas krimināltiesiskajā regulējumā ir lietots "valsts nodevības" termins, taču izpratne par šā jēdziena tvērumu ir bijusi mainīga un atbilstīga katram Latvijas vēstures laika posmam un geopolitiskajai situācijai. Respektīvi, "valsts nodevība" aptvēra tādu noziegumu izdarī̌šnu (kā kara, tā miera laikā), ko likumdevējs uzskatīja par vēršanos pret valsti un nacionālās drošības interesēm. Savukārt "spiegošanas" jēdziens kā atseviškła noziedzīgu nodarījumu grupa Latvijas krimināltiesiskajā regulējumā parādījās tikai Latvijas PSR KK. "Valsts nodevības" jēdziens ietvēra ne tikai valsts aizsargājamas informācijas nodošanu ārvalsts rīcībā, par ko šobrīd KL ir paredzēta 
atbildība, bet arī palīdzības sniegšanu ārvalstij veikt ar vardarbību nesaistītas darbības pret valsts neatkarību, teritoriālo vienotību un nacionālās drošības interesēm. Izṇemot "valsts nodevības" jēdzienu no Latvijas krimināltiesiskā regulējuma, šāda atbildība šobrīd KL vairs nav noteikta, tādēḷ domāju, ka "valsts nodevības" jēdziens Latvijas krimināltiesiskajā regulējumā ir jāatjauno, lai nodrošinātu Latvijas Republikas Satversmes preambulā nostiprināto principu krimināltiesisko aizsardzību.

\section{Ārvalstu izlūkdienestu radītais apdraudējums valsts interesēm}

"Spiegošanas", tostarp "valsts nodevības” noziegumi, ņemot vērā šo darbību ciešo saistību, apdraud nacionālās drošības intereses. Tiesību zinātnes pētniece D. Kurtina (D. Curtin) apgalvo, ka drošība mūsdienās ir daudz plašāks jēdziens nekā klasiskā izpratne par valsts spēju izmantot militāru spēku, lai aizsargātu valsti pret ārējiem uzbrucējiem, tādējādi nodrošinot tās neatkarību [2, 8]. D. Kurtina skaidro, ka mūsdienu pasaulē draudi drošībai ir skatāmi no dažādiem aspektiem, piemēram, organizētās noziedzības, terorisma, korupcijas, nelegālās imigrācijas, spiegošanas u. c., jo šìs problēmas var apdraudēt valsts teritoriālo vienotību no iekšpuses $[2,8]$. Minētais pierāda, ka pret valsts drošību var vērsties ne tikai ar militāriem līdzekḷiem, bet apdraudējums ir saskatāms arī ar vardarbību nesaistītā rīcībā pret nacionālās drošības interesēm. Tādēl spiegošanas un valsts nodevības noziegumu radìto apdraudējumu nacionālās drošības interesēm nedrīkst nenovērtēt vai novērtēt par zemu, jo, kā norādīts Nacionālās drošības likuma 1. panta otrajā dạ̦ā, nacionālās drošības garantēšana ir valsts pamatpienākums [19].

Nacionālās drošības koncepcijā ir noteikts, ka viena no nacionālās drošîbas apdraudējuma novēršanas prioritātēm, līdzās militāro draudu un ekonomisko interešu apdraudējuma novēršanai, ir ārvalstu izlūkdienestu radītā apdraudējuma novēršana [18]. SAB vērtējumā ārvalstu izlūkdienestu darbs pret Latviju saglabājas kā viens no būtiskākiem apdraudējumiem ilgtermiņa drošībai [21, 2].

Baltijas valstīs visaktīvāk darbības un intereses izvērš Krievijas izlūkdienesti, to savos pārskatos ir atzinuši Baltijas valstu specdienesti - Latvijā SAB [21, 2], Igaunijā KaPo [8, 12], Lietuvā Valsts drošības departaments (VSD) [27, 4]. Taču, kā norāda Lat vijas Drošības policijas priekšnieks N. Mežviets, šobrīd Krievijas izlūkdienestu aktivitāšu līmenis Latvijā ir vērtējams kā vidējs [4]. Minētais liecina, ka spiegošanas un valsts nodevības nozieguma risks Latvijā pastāv, un šā nozieguma radītais apdraudējums nacionālās drošības interesēm ir aktuāls problēmjautājums Latvijā.

Izlūkdienestu un drošības politikas pētnieki P. Velšs (P. F. Walsh) un S. Millers (S. Miller) norāda, ka pasaules valstu lielākā dạa veic aktīvas un mērḳtiecīgas izlūkošanas aktivitātes citās valstīs, lai atbalstītu savu valstu valdības virknē lēmumu politisku, diplomātisku un ekonomisku - pieņemšanas procesu [28, 20]. Minētais liecina, ka ārvalsts izlūkdienesta interešu loks ir plašs. Arī SAB uzsver, ka jebkura izlūkdienesta mērḳis ir iegūt apsteidzošu un, vēlams, publiski nepieejamu informāciju 
par sabiedriskiem, politiskiem, ekonomiskiem un militāriem procesiem mērḳa valstī, lai gūtu priekšrocības savas valsts rīcībai. Bez informācijas vākšanas ārvalsts izlūkdienesti ìsteno arī aktīvos pasākumus, kuru mērḳis ir ietekmēt lēmumu pieņemšanu un sabiedrības viedokli $[22,7]$.

No minētā secināms, ka ārvalstu izlūkdienestu aktivitātes citās valstīs ir pasaulē izplatìta un pien̦emta metode, kā iegūt savai valstij priekšrocības interesējošās jomās, taču jāṇem vērā arī izlūkošanas otra puse - tā ir spiegošana un ar vardarbību nesaistīta rīcība pret citas valsts nacionālās drošības interesēm, pēc būtības - kaitnieciska un prettiesiska.

Nacionālās drošîbas koncepcijā ir skaidrots, ka ārvalstu izlūkdienestu darbību pret Latviju un tās interesēm var iedalīt politiskajā, militārajā un ekonomiskajā izlūkošanā. To darbība var tikt vērsta gan pret Latvijas nacionālās drošības interesēm, gan var apdraudēt NATO un ES kopējo drošību [18].

Militārās izlūkošanas tehnoloğiju attīstības pētnieki D. Torlečters (D. Thorleuchter) un D. Van den Pols (D. Van den Poel) apgalvo, ka tradicionāli militārajā izlūkošanā tiek vākta informācija par ienaidnieka armijas spējām, īpaša uzmanība tiek pievērsta ieroču sistēmām, izmantotajām tehnologijām, kā arī nākotnes ieroču sistēmām un to piedāvātajām iespējām [24, 3433]. SAB norāda, ka 2014. gadā militārās izlūkošanas ziṇā Krievijas izlūkošanas interešu lokā viena no prioritātēm bija NATO dalībvalstu, īpaši ASV, bruṇoto spēku izvietošana Baltijas valstīs $[22,7]$. Minētais apstiprina, ka ārvalstu izlūkdienestu darbība var tieši apdraudēt valsts ārējo drošību un valsts militārās aizsardzības intereses, tostarp arī neatkarību vai teritoriālo vienotību.

Ekonomiskās izlūkošanas ziņā tradicionāli tiek vākta informācija par ekonomikas sektoru, tirdzniecību un industriālo ražošanu [28, 16]. P. Velšs un S. Millers skaidro, ka ārvalstu izlūkdienesti vēsturiski par visām interesējošām valstīm ir vākuši informāciju par stratēgiskiem tirgiem, tirdzniecības pieeju, produktiem un informāciju par patentiem, piemēram, par medikamentiem un to sastāvu, par dubultā pielietojuma tehnologijām, piemēram, datoru mikroprocesoriem, ko var izmantot arī aizsardzỉbas jomā, atjaunojamo resursu pētniecības projektiem. N̦emot vērā, ka biznesa attīstība notiek publiskā telpā, gan sabiedrotie, gan ienaidnieki var būt pretinieki ekonomiskajā spiegošanā $[28,16]$.

D. Torlečters un D. Van den Pols vērš uzmanību, ka pēdējos gados Vācijas pretizlūkošanas darbinieki ir norādījuši uz spiegošanas aktivitātes pieaugumu Vācijas pētniecības un tehnologiju attīstības jomā. Spiegošanas aǵenti tiek pieñemti darbā zinātnes un tehnologiiju sfērās, viṇi pārstāv ārvalstu izlūkdienestus no Krievijas, Ķinnas un Tuvo Austrumu, un Ziemel̦āfrikas valstīm [24, 3433]. D. Torlečters un D. Van den Pols norāda, ka tādēl būtisks ir uzdevums aizsargāt pret ārvalstīm un konkurentiem nacionālo industriālo pētniecību un tehnologiiju attīstību [24, 3433]. Neapšaubāmi, valsts uzdevums ir aizsargāt savu industriālo ražošanu un būtībā visu ekonomikas sektoru pret ḷaunprātīgu savu resursu un intelektuālā potenciāla nozagšanu, jo šādā veidā ir iespējams nodrošināt valsts un sabiedrības labklājības un ekonomiskās intereses. 
Savukārt politiskā izlūkošana attiecas uz politisko lēmumu pien̨emšanas procesu un ārvalstu līderu politisko un ekonomisko nodomu noskaidrošanu. SAB skaidro, ka Latvijā 2014. gadā Krievijas izlūkošanas interešu loks tika pielāgots svarīgākajiem politiskajiem un drošỉbas notikumiem. Pastiprināta uzmanība tika veltīta notikumiem Ukrainā, kā arī Latvijas, NATO un ES reakcijai pret Krieviju. Austrumu partnerības samits Rīgā un Latvijas prezidentūras prioritātes ES Padomē arī izraisīja ārvalstu izlūkdienestu interesi. Saeimas vēlēšanas, politisko partiju izredzes un informācija par politiskajiem līderiem un amatpersonām arī bija izlūkdienestu dienaskārtībā [22, 7].

Nacionālās drošības interesēm īpaši kaitē politiskā izlūkošana, kas ārvalstij sniedz priekšrocības pielāgot savu politiku vai iedarboties uz mērḳa valsts politiskajiem procesiem un sabiedrisko domu. Šis apstāklis īpaši jāuzsver, jo no politisko lēmumu pieṇemšanas un politiskiem uzstādījumiem vistiešāk ir atkarīga visas sabiedrības labklājība un tās interešu nodrošināšana visās valsts dzìves un drošîbas jomās.

\section{Ārvalstu izlūkdienestu radītais apdraudējums fiziskām personām}

Ne tikai ārvalstu izlūkdienestu interesējošo jomu loks ir plašs, bet arī izmantotās metodes ir dažādas, lai iegūtu interesējošo informāciju vai saņemtu cita veida palīdzību. Politikas un vēstures zinātnes pētnieks P. H. J. Deivis (P. H. J. Davies) skaidro, ka kopš 2. pasaules kara galvenais izlūkošanas veids bija tehniskā izlūkošana (Techint), lai gan arī cilvēkizlūkošanai (Humint) vienmēr ir bijusi svarīga loma ārvalstu izlūkdienestu interesējošās informācijas iegūšanai $[3,116]$. SAB konstatē, ka ārvalstu izlūkdienesti savā darbībā Latvijā izmanto dažādas metodes - informācijas iegūšanu no kontaktpersonām un informācijas avotiem, informācijas iegūšanu no atklātajiem avotiem, kā arī tehnisko un signālizlūkošanu, t. sk. pārtverot un analizējot komunikāciju datu plūsmu [21, 3].

No minētā secināms, ka ārvalstu izlūkdienestu radītais apdraudējuma apjoms ir plašs un ievērojams, jo tas nav attiecināms tikai uz fizisko vidi, bet arī uz kibervidi. Informācijas drošības politikas pētniece C. Evereta (C. Everett) uzsver, ka mūsdienās nemainās spiegošanas mērḳi, - vairāk mainās metodes, kā iegūt informāciju. Kiberspiegošana ir drauds, kas tikai pieaug, jo pasaule arvien ciešāk saistās kopējā informācijas tīklā [5, 5].

Izlūkošanas un pretizlūkošanas pētnieki L. A. Kramera (L. A. Kramer) un R. J. Hērs (R. J. Heur) apgalvo, ka ārvalstu izlūkdienestu mērḳis var būt jebkura persona, izvēlētais mērḳis ir atkarīgs no tā, kādu informāciju ārvalstu izlūkdienests vēlas iegūt vai kādu palīdzību vēlas saṇemt. Taču visbiežāk ārvalstu izlūkdienestu mērḳis ir personas, kurām ir pieeja klasificētai informācijai $[9,50]$.

SAB skaidro, ka Latvijā izplatìta ir metode, ka kontaktu uzsākšanai un informācijas iegūšanai izlūkdienestu virsnieki, stādoties priekšā kā vēstniecības diplomāti, vēršas pie interesējošās personas tās darba vietā. Interesi par konkrētiem jautājumiem izlūki visbiežāk pamato ar darba nepieciešamību, klasificēta informācija no kontaktpersonām netiek prasīta. Tādējādi izlūkdienesta virsnieki balansē uz robežas - formāli viṇu darbība atbilst diplomātiskajam statusam, tomēr vienlaikus 
tieši izlūkdienestu virsniekam raksturīgās prasmes kontaktu veidošanā un sarunas virzīšanā šādās situācijās ḷauj iegūt izlūkdienestam nepieciešamās ziṇas un publiski nepieejamus ekspertu viedokḷus [21,3].

Personas var tikt uzrunātas ne tikai Latvijas teritorijā. Par vienu no Krievijas Federālā drošības dienesta (FSB) plaši lietotām metodēm, strādājot no Krievijas teritorijas, SAB min Latvijas valstspiederīgo uzrunāšanu, piedāvājot sadarbỉbu un par to saṇemot atlīdzību. Šāda interese īpaši tiek izrādīta par Latvijas valstspiederīgajiem, kuri regulāri ceḷo uz Krieviju. Bieži šādus tiešus sadarbības piedāvājumus saṇem personas, škiērsojot robežu [21, 5].

SAB secina, ka augsts risks saglabājas Latvijas iedzīvotājiem, kuri periodiski vai ilgstoši uzturas Krievijā. Latvijas jaunieši un studenti, ipaši Krievijā studējošie, ir pakḷauti FSB interešu sfērai. Šantāža un draudi periodiski tiek izmantoti, lai nodrošinātu sadarbību ar vēlamām personām $[22,7]$.

N̦emot vērā visu par ārvalstu izlūkdienestu apdraudējumu minēto, redzams, ka ārvalstu izlūkdienestus kā Humint resursi visvairāk interesē:

1) personas, kurām ir pieeja klasificētai informācijai;

2) Latvijas valstspiederīgie, kuri škēerso Krievijas robežu;

3) personas, kuras strādā ekonomikas, zinātnes, aizsardzības, valsts drošības jomā;

4) politiki un valsts amatpersonas;

5) jebkurš valstspiederīgais, kurš ir gatavs sniegt palīdzību un sadarboties ar ārvalstu izlūkdienestu.

Minētais liecina, ka ārvalstu izlūkdienestu mērḳis var būt jebkurš valstspiederīgais, tāpēc ārvalstu izlūkdienestu apdraudējums valsts iekšējās un ārējās drošības interesēm ir sevišķi būtisks un ievērojams.

\section{Secinājumi un priekšlikumi}

1. Jēdziens "spiegošana" ir raksturojams kā prettiesiskas darbības ar aizsargātu informāciju ārvalsts interesēs, savukārt jēdziens "valsts nodevība" ir plašāks un ir saistāms ar valstspiederīgo lojalitātes, saiknes un pienākuma pārkāpšanu pret savu pastāvīgās mītnes valsti, aptverot ne tikai spiegošanas pazīmes, bet arī aizliegumu palīdzēt ārvalstij veikt vardarbīgas un ar vardarbību nesaistītas darbības pret valsts neatkarību, suverenitāti, teritoriālo vienotību un nacionālās drošības interesēm. Mūsdienās demokrātiskas valstis izmanto abus jēdzienus, piemērojot tos kā kara, tā miera laikam.

2. Vēsturiski Latvijas krimināltiesiskajā regulējumā ir bijis ietverts jēdziens "valsts nodevība”, taču esošais krimināltiesiskais regulējums aptver vienīgi jēdziena "spiegošana" būtỉbu.

3. Spiegošanas un valsts nodevības noziegumi ir būtisks apdraudējums ne tikai Latvijas drošỉbas interesēm, bet arī ekonomikas un politikas interesēm, valsts neatkarībai, konstitucionālajai iekārtai, teritoriālajai vienotībai, sabiedrības brīvas attīstības perspektīvai un labklājībai, jo ārvalsts varas institūcijas un 
ārvalsts izlūkdienestus interesē detalizēta informācija par minētajām jomām, kā arī iespējas ietekmēt šĩs jomas un to attīstību savās interesēs. Tādējādi spiegošanas un valsts nodevības noziegumi dod ārvalstij priekšrocības, pieñemot lēmumus par ārpolitiku, ekonomiskajām un militārajām aktivitātēm, kas ir pretējas Latvijas interesēm. N̦emot vērā ievērojamo apdraudējumu, valsts pienākums ir noteikt krimināltiesiskos mehānismus, lai mazinātu šo apdraudējumu un spētu piemērot atbildību par radīto apdraudējumu nacionālās drošības interesēm.

4. Politiskā izlūkošana ir viena no kaitīgākajām izlūkošanas jomām pret Latvijas nacionālās drošības interesēm, jo tā ārvalsts varas institūcijām sniedz priekšrocības pielāgot savu politiku, ietekmēt Latvijas politiskos procesus un sabiedrisko domu. N̦emot vērā darbā apskatītos piemērus, vienlīdz būtisks ir ārvalstu izlūkdienestu radītais apdraudējums fiziskām personām, jo ārvalstu izlūkdienestu mērḳis var būt jebkurš valstspiederīgais.

5. Ārvalsts varas institūcijas un ārvalstu izlūkdienestus interesē ne tikai valsts aizsargātas informācijas iegūšana, bet arī cita veida palīdzības no valstspiederīgo puses saṇemšana ar vardarbïbu nesaistītu darbïbu veikšanai, kas vērstas pret valsts neatkarību, suverenitāti vai teritoriālo vienotību - ārvalsts mērḳu un interešu sasniegšanai. Tāpēc lietderīgi atjaunot KL "valsts nodevības" jēdzienu, noškirirot darbības, ko pret valsti vērš Latvijas valstspiederīgais, no darbībām, ko izdara ārzemnieks.

6. Ārvalsts izlūkdienestu mērḳis ir radìt priekšrocības attiecīgajai ārvalstij ietekmēt Latvijas politisko lēmumu pien,emšanu, ekonomisko izaugsmi, militāro aizsardzību, sabiedrisko domu u. c. jomas. Personai sniedzot palīdzību šo mērḳu sasniegšanā, tiek apdraudētas nacionālās drošības intereses un Satversmē nostiprinātie valsts principi aizsargāt konstitucionālo iekārtu, suverenitāti, teritoriālo vienotību. No minētā secināms, ka valsts nodevības tiešais objekts ir valsts intereses, taču vienlīdz tiek aizskartas arī sabiedrības intereses pēc drošības un stabilitātes, ekonomiskās labklājības, sabiedriskās domas attīstības un pamattiesību nodrošināšanas.

N̦emot vērā objektu, iesaku kriminālatbildību par valsts nodevību paredzēt KL, nošḳirot no spiegošanas panta.

\section{Criminal Law on Espionage and Treason in the Baltic States}

\section{Abstract}

The geopolitical environment once again has brought tension between the West and Russia, and in this on-going informational competition such crimes as treason and espionage become topical issues. Four people have been convicted of treason in Estonia 
over the past six years, while in Lithuania three criminal proceedings for espionage where initiated last year alone. It is a large number for the Baltic States, considering difficulties to prove the mentioned crimes. However, no one has been convicted of espionage in Latvia since regaining of independence.

In the article the author compares the existing criminal law of the three Baltic States to discover and analyse possible theoretical as well as practical problems in applying liability for acts of treason and espionage in Latvia. The author proves that the Criminal Law of the Republic of Latvia is incomplete and insufficient to protect national security interests - the Criminal Law does not "recognise" treason as crime, and the legal regulation of espionage is outdated and unsuitable for the present situation.

Keywords: Criminal Law, espionage, treason.

\section{Literatūra un avoti}

1. 1903. gada 22. marta Sodu likumi: Tulkojums ar paskaidrojumiem un ar motīviem par Latvijas valdības laikā izdotiem grozijjumiem. Tieslietu ministrijas sevišḳas komisijas sagatavojumā. Trešais izdevums. Rīga: Valsts tipogrāfija, 1930.

2. Curtin, D. Top secret Europe. University of Amsterdam, 2011. Iegūts no: http://dare.uva.nl/ document/2/103309 [sk. 02.02.2015.].

3. Davies, P. H. J. Information warfare and the future of the spy. Information, Communication E Society, 1999; 2 (2).

4. Drošìbas policija: Krievijas specdienestu aktivitāšu līmenis Latvijā ir vidējs. 2015. LETA. Iegūts no: http://apollo.tvnet.lv/zinas/drosibas-policija-krievijas-specdienestu-aktivitasu-limenislatvija-ir-videjs/687505 [sk. 30.04.2015.].

5. Everett, C. The lucrative world of cyber-espionage. Computer Fraud \& Security, 2009; 7.

6. Gill, P., Phythian, M. What is Intelligence? In: Intelligence in an Insecure World. $2^{\text {nd }}$ edition. Cambridge: Polity Press, 2006.

7. Igaunijas Sodu kodekss (Karistusseadustik): EE likums. Iegūts no: https://www.riigiteataja.ee/ akt/112032015021 [sk. 30.04.2015.].

8. KaPo Annual Review 2013. Iegūts no: https://www.kapo.ee/cms-data/_text/138/124/files/kapoannual-review-2013-eng.pdf [sk. 14.03.2015.].

9. Kramer, L. A., Heur, R. J. America's increased vulnerability to insider espionage. International Journal of Intelligence and CounterIntelligence, 2007; 20(1).

10. Krastiņš, U. Krimināllikumam 10 gadi: tapšana, attīstība, perspektīva. Juridiskā Zinātne, 2010; 1.

11. Krievijas Kriminālkodekss (Уголовныцй кодекс Российской Федерации): RU likums. Iegūts no: http://pravo.gov.ru/ [sk. 30.04.2015.].

12. Krimināllikums: LR likums. Latvijas Vēstnesis, Nr. 199/200, 08.07.1998.

13. Krimināltiesības - attīstības tendences Eiropas un nacionālajās tiesībās, attiecības starp I un II pīlāru, ieviešanas metožu labākā prakse. V. Liholaja, B. Bērziṇa, K. Mekons u. c. Rīga, 2009. Iegūts no: https://www.tm.gov.lv/files/archieve/lv_documents_petijumi_kriminaltiesibas2.doc [sk. 02.04.2015.]. 
Laura Platace. Spiegošanas un valsts nodevības krimināltiesiskais regulējums nacionālās drošības kontekstā

14. Latvijas Padomju Sociālistiskās Republikas kriminālkodekss. Oficiālais teksts ar pielikumiem, kuros ievietoti pa pantiem sistematizēti materiāli. Latvijas PSR Tieslietu ministrija. Rìga: Liesma, 1976.

15. Latvijas PSR Kriminālkodeksa komentāri. J. Dzenīša un A. Niedres vispārīgā redakcijā. Rīga: Avots, 1982.

16. Lietuvas Kriminālkodekss (Lietuvos Respublikos Baudžiamojo kodekso): LT likums. Iegūts no: http://www3.lrs.lt/pls/inter3/dokpaieska.showdoc_e?p_id=366707\&p_tr2=2 [sk. 07.02.2015.].

17. Mincs, P. Krimināltiesības. Sevišḳā daḷa. Ar V. Liholajas komentāriem. Rīga: Tiesu namu aǵentūra, 2005.

18. Nacionālās drošības koncepcija (informatīiā daḷa). Latvijas Vēstnesis, Nr. 45 (4443), 22.03.2011.

19. Nacionālās drošības likums: LR likums. Latvijas Vēstnesis, Nr. 473/476 (2384/2387), 29.12.2000.

20. Par grozījumiem un papildinājumiem Latvijas PSR kriminālkodeksā un Latvijas PSR kriminālprocesa kodeksā: LR likums. Ziņotājs, Nr. 33, 29.08.1991.

21. SAB 2013. gada darbības pärskats. Iegūts no: http://www.sab.gov.lv/downloads/2013_parskats. pdf [sk. 14.03.2015.].

22. SAB 2014. gada darbības pārskats. Iegūts no: http://www.sab.gov.lv/downloads/2014_parskats. pdf [sk. 30.04.2015.].

23. Taylor, S. A, Buchanan, K. Treason: Tis Worse than Murder. The Oxford Handbook of National Security Intelligence. London: Oxford University Press, 2010.

24. Thorleuchter, D., Van den Poel, D. Protecting research and technolgy from espionage. Expert Systems with Applications, 2013; 40.

25. Tost, D. German domestic security agency finds Russia reverting to KGB measures. 2015. Iegūts no: http://www.euractiv.com/sections/global-europe/german-domestic-security-agencyfinds-russia-reverting-kgb-measures-312430 [sk. 30.04.2015.].

26. Vācijas Kriminālkodekss (Strafgesetzbuch): DE likums. Iegūts no: http://www.gesetze-iminternet.de/englisch_stgb/englisch_stgb.html [sk. 02.04.2015.].

27. VSD Annual Threat Assessment 2013. Iegūts no: http://www.vsd.lt/Files/ Documents/635448351234307500.pdf [sk. 14.03.2015.].

28. Walsh, P. F., Miller, S. Rethinking "Five Eyes". Security Intelligence Collection Policies and Practice Post Snowden. Intelligence and National Security, 2015. 